\title{
EMBRACING SEGREGATION: THE RISE OF A RELIGIOUS EDUCATIONAL SYSTEM IN ISRAEL (SHAS)
}

\author{
Batia Siebzehner \\ Beit Berl College and Truman University \\ Hebrew University of Jerusalem, \\ Israel \\ msbatsib@msce.huji.ac.il \\ David Lehmann \\ Cambridge University, England \\ adl1@cam.ac.uk
}

\begin{abstract}
RESUMEN
Este articulo estudia el surgimiento de una nueva corriente educacional étnico-religiosa en Israel, Maayan Hachinuch Hatorani ("El Manantial de la educación de la Torah"). Ella fue fundada en 1984 y está bajo el control del liderazgo de Shas, un movimiento de renovación religiosa y de identidad "sefaradi-oriental. Las politicas de discriminación implementadas en las instituciones Ashkenazies ultra-ortodoxas, llevó a los lideres del movimiento Shas a fundar un nuevo sistema, capaz de responder a las dificultades de la población marginalizada. Las escuelas de Shas, que pertenecen y son subsidiadas por el Ministerio de Educación, son además agentes de socialización, tanto para niños como para padres que están alejados de un estilo de vida religioso. Así, a través de la creación de estrategias para la transmisión del conocimiento y el comportamiento, la nueva corriente educacional desafia al proyecto nacional secular y contribuye a la formación de una nueva esfera cultural.

En este articulo exploramos la manera en que el movimiento religioso hace uso de la educación como medio para extender la movilización social y fortalecer los lazos de solidaridad. La investigación está basada en un estudio etnográfico llevado a cabo durante los años 2000-2005 en tres ciudades en Israel. A través de la trasformación de los límites culturales y la institucionalización de normas que contradicen los principios que sustentan las relaciones entre el gobierno y la educación masiva, el sistema fundado por Shas contribuye a forjar un judaismo israeli ultra-ortodoxo basado en una identidad étnica primordial. El caso contribuye tanto a entender el desafio que la religión le plantea a la educación moderna como a analizar nuevos desarrollos dentro del judaismo.
\end{abstract}

Palabras Clave: Educación, enclaves, etnicidad, Israel, judaismo, límites culturales, movimientos sociales, religión, sefaradies, Shas, ultra ortodoxia, $t$ shuva (retorno).

\section{ABSTRACT}

The paper focuses on the emergence of a new religious-ethnic cducational stream in Israel, Maayan Hachinuch Hatorani, ("The Wellspring of Torah Education"). It was founded in 1984 and is controlled by the leadership of Shas, a movement of religious renewal and 
Sephardic-Oriental identity. Discriminatory policies, implemented by the ultra-Orthodox Ashkenazi establishment, brought the leaders of the Shas movement to initiate a new system capable of responding to the hardship of a marginalized population. Shas schools, functioning within and being supported by the Ministry of Education, also became socializing agents for children and parents that were far from religious lifestyle. Thus, through the creation of strategies for the transmission of knowledge and behavior, the new stream challenges the secular national project, and contributes to the formation of a new cultural sphere.

In this paper we explore how a religious movement embraces education to foster social mobilization and group solidarity. The research is an ethnographic study that was conducted between 2000-2005 in three cities in Israel. By transforming cultural boundaries and institutionalizing norms that contradict in some respects the principles underlying the relationship between government and mass schooling, Shas's education systems contributes to forge an Ultra-Orthodox Israeli Judaism based on an ethnic type of primordial identity. The case contributes to understand the challenges that religion holds to modern systems of education and to analyze new developments in Judaism.

KEY WoRDS: Cultural boundaries, education, enclaves, ethnicity, Israel, Judaism, religion, Sephardim, Shas, social movement, Ultra Orthodox, t'shuva (return).

\section{THE EDUCATIONAL SYSTEM REPRESENTING SOCIAL ENCLAVES}

Israel can be thought of as a society of enclaves - political legal, cultural, social and territorial. In the words, for example, of Horowitz and Lissak "social enclaves tend to form around movements which act as secondary centers that mobilize and allocate resources and commitments, receiving continuity through socialization and indoctrination" (Horowitz and Lissak 1987) p. 28). The use the word enclave in part simply draws attention to the degree of separation, which keeps groups in Israeli society more sharply apart than in comparable high-income countries. It denotes visible or palpable boundaries backed by a degree of institutionalization, and also the superimposition of several different boundaries - for example territory, race, marriage education, language, and dress codes. In contrast to the ghettoes or banlieues of Western Europe, which marginalize a certain category of group -notably immigrants and racial minorities-Israel's enclave pattern applies to a wide range of social groups and criss-crosses the entire social structure.

The development of the Israeli educational system can be analyzed as the resuit of the country's changing institutional and cultural boundaries. Since the founding of the state, Israeli leaders considered education as a powerful tool for the elimination of differences among immigrants, and the creation of a unified Israeli nation. Educational policy envisaged the reintegration of the separate Jewish cultural heritages into a collective identity, whose main bearer would be the Zionist State. Thus, the educational system has focused not only on the process of socialization, but also on the creation and transmission of symbols that represented the Jewish identity in the new state. However, the educational system also reflects an enclave pattern whose roots spring from the earliest development of the Zionist movement in Palestine in 1902. The division of the 
education system according to religious criteria (secular, national religious ${ }^{1}$, ultra-Orthodox) was inherited from the pre-State period (the Yishuv) when non-state Jewish institutions ran their own schools. These separate arrangements have been preserved in parallel to the patronage power of political parties in the state, also inherited from the pre-State period when the various Zionist parties - left, right, centre, religious and secular and various permutations of these - had, in accordance with enclave principle, their own kibbutz settlements, cooperatives, medical services, football teams and much else besides.

The ultra-Orthodox haredim ${ }^{2}$ were, on the founding of the state if lsrael, granted state-funded educational autonomy and legal prerogatives over personal status law for all Jews (Zameret, 1997). Today, the educational enclaves provide a separate education system for Arabs and four main educational systems for Jews of different religious affiliation -including, as we shall see, the 'Shas' network known as 'The wellspring of Torah education' (HaMa'ayan Hachinuch Hatorani). The state-funded education is divided, for the Jewish population, into a mainstream secular system (about 66 per cent), a "national religious" system (about 21 per cent), and an ultra-Orthodox system (around 13 per cent). The existence of the different streams in public education implied the state's formal recognition of the ethnic and religious segmentation in society.

The Ma'ayan Hahinukh Hatorani, the educational stream controlled by the leadership of Shas, the party of religious renewal and Sephardic-Oriental (Middle Eastern and North African) identity founded in 1984, is a paradigmatic instance of the construction of a segmented religious identity within the frame of the secular state. While the ultra-Orthodox educational system controlled by the Ashkenazi religious authorities of Eastern European origin was a prolongation of the system already in place in the pre-independence period, the Orthodox Sephardic system is a recent creation, and a state product originating with the entry of Shas into government. Through Ma'ayan Hahinukh Hatorani, Shas competes with the state as an agent of primary education and it thus competes for the support and loyalty of constituents who fell that the state doesn't

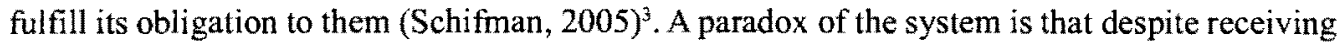
increasing levels of funding from the state, ultra-orthodox educational streams have effectively evaded state supervision and in many senses are not obligated to meet state curricular standards. One of the greatest achievements of the Shas' party in 2008, under Olmert's government, is the establishment of a law that exempts ultra-orthodox schools from the "core" of secular studies (English, mathematics, language) but allows them to receive higher state subsides. As I will

1 National Religious schools were at first established in recognition of the existence of a religious wing to Zionism at the founding of the state and before. Their curriculum is more religious than that of state secular schools, and it is a reality that their pupils tend to achieve less and to come from poorer backgrounds. They are run by the Ministry of Education, unlike the schools of the ultra-Orthodox and Shas which are funded by the Ministry but managed independently.

2 Literally, those who live in fear of God. Haredim, here, are almost all Ashkenazi Jews, heirs to the RussianPolish tradition; later that changes as we shall see.

3 Ma'ayan Hahinzkh Fatorani schools that enroll children from non-ultra-orthodox families are located in statistical areas that are more Sephardic and less ultraorthodox than the statistical areas in which the network's Talmud torahs are located. (Schiffman 2005:104). 
show, its educational practices and institutions challenge the secular national project, and contribute to the separation of collective and individual's life into new cultural spheres under the auspices of religious organizations.

In this paper, we will discuss some of Shas' educational strategies and practices aimed at forging an Orthodox Israeli Judaism based on an ethnic type of primordial identity. We think that this case helps understand the growing of challenging over premises previously "taken for granted" in the cultural domain. The Shas educational system has created new strategies for the transmission of knowledge and the regulation of behavior, most of which are removed from the ideologies underlying Israeli education. Shas's educational practices have transformed cultural boundaries and institutionalized norms that contradict in some respects the principles underlying the relationship between government and mass schooling in most modern states (Popkewitz 1991:56).

\section{THE RISE OF A NEW ULTRA-ORTHODOX EDUCATIONAL NETWORK}

One of Shas's distinctive characteristics is its fascinating mix of "ideology and pragmatism "(Arian and Shamir 1986). The party's representation in the Knesset (the Israeli Parliament) has increased from four in 1984 to 17 in 1999, i.e. from 3 percent to 13 percent of the vote, being the third largest party in the Knesset and decreased to 11 since 2002 being in 2008, like the Likud Party, the third largest one. When the party is part of the coalition, it influences government allocations to the ultra-orthodox sector, redirecting large amounts of state funds to the Sepharadic public and institutions. Within this context, Shas deftly maneuvers the system, and uses it in order to extract resources for its educational enterprise. It also takes advantage of the loose supervision government agencies exercise over educational institutions, and is able to divert funds, e. g. by using subsides provided for education for religious affairs, for the support of informal religious activities, and even by transferring educational funds to the party budget. Since Shas' participation in government, subsidies for the ultra-orthodox in Israel have not only increased, but have also been distributed in greater part to ultra-orthodox Sephardim (Berman, 2000). When the Ministry of Education attempted to tighten control over budget allocation, Shas circumvented the new rules by establishing formally independent organizations, such as "The Fund for the Education of the Children of Israel" (Tesler 2001).

The Ma'ayan Hahinukh Hatorani's documents and religious directives adopt methods and techniques from the modern secular system and use them for the construction of a new social space. In developing its educational network, Shas "piggybacked" on the concessions granted by the government in 1948 to ultra-Orthodox Ashkenazi communities. These were allowed to run a separate system of publicly supported schools and Yeshivas, with curricula imported from pre-World War II Eastern Europe, which contained minimal amounts of modern and secular subjects. For a modern democratic government, this was an unusual arrangement. It stemmed from the fact that East European Jewish society and culture had been wiped out by the Holocaust, and it was an attempt to allow the remnants of this civilization to reconstruct at least some aspects of their culture. It was also the result of political equilibrium between different forces in the political realm. Shas has taken advantage of the rules of liberal democracy (Barzilai 2003) 
and attempted to replace the ideologies of individualism and rationality, embedded in modem schooling, with ideas arising from religious authority.

In order to understand the content of Shas's educational project, we should start by presenting the central element of its narrative, which Yeshiva students absorb from their teachers and party members and voters from its leaders. This narrative describes Sephardic cultural experience in the new state in terms of cultural victimization, a story whose focus is the Ashkenazim's alleged campaign aimed at the destruction of the "jewel" or "crown" of the traditions of North African Judaism. The movement's representatives emphasize the fact that North African Judaism, unlike the European counterpart, did not experience Haskala, the Jewish version of the Enlightenment, which marked a fundamental watershed in Eastern European Jewish history. Due to the absence of pressures generated by the process of modernity in the lands of their ancestors, they were spared the cleavage between orthodoxy and secularism, which became central in European and North American Jewry. This is a world in which, despite variations in the intensity of religious observance and a measure of toleration of dissent, the central traditions of a Jewish way of life, the rituals of the life cycle, the taboos surrounding sexual relations, the practice of endogamy, and the Rabbis' authority were respected and mostly unquestioned. The portrait is that of a society whose central dynamics resided in the practice of traditional faith, embedded in the rhythms of everyday life, untainted by the conflicts between the orthodox and the secular, and untouched by the Holocaust (except for a brief period in Algeria, during Vichy).

The Shas network had, in 2001-02, just under 16000 students in elementary and intermediate schools and about 15,000 in kindergartens, and a teacher-training college. The numbers had increased slowly. Although these figures are relatively small, they have an important symbolic meaning for the educational system in Israel. Shas leaders regularly emphasize the significance of the network and its important role in the political dealings. The "Talmud torah" and the "schools" are the main types of schools in the network. The Talmud torahs mainly focus on religious studies and serve children from traditional Sephardic ultra-orthodox families. The other schools in the network teach more secular studies and serve children from traditional families or those whose parents have recently become more religiously observant.

Leaders of the movement have invoked several factors to legitimize the development of a different educational network. Some emphasize a sense of social injustice due to the increasing gap within the state system between the pupils of Oriental origin and the Israelis of EuropeanAmerican origin. Others refer to a discriminatory policy carried out by the Ashkenazi Orthodox learning institutions (yeshivas) against the Oriental Orthodox population. But rather than a compensatory mechanism, party leaders and ideologues present the Shas educational system as a central device in the project of a "religious revolution", whose main objective is "to impose in a

4 Data from the Ministry of Education's department for "recognized, non-official funded" education (e.i., the institutions of the Aslikenazi ultra-Orthodox and Shaz). Shas tends to claim much more, and of course the funding received by the network is calculated according to the number of pupils, so these numbers are a matter of controversy. This, however, is an official source. 
democratic way a religious lifestyle on the entire population of lsrael, thus changing the relations between the secular majority and the religious minority" (Tesler 2001). They expect schools to consolidate and disseminate the vision of their undisputed leader, Rabbi Ovadia Yosef, in matters of renewal of religious observance ( $t$ 'shuva) and try to attain these aims by appropriating resources and jurisdictional autonomy from the state.

\section{LEGITIMATING THE EDUCATIONAL NETWORK: INEQUITY AND DISCRIMINATION}

Israel is a country of immigrants containing about seventy different Jewish ethnic groups, as well as a non-Jewish, mainly Arab, minority comprising about 19 percent of the population. The government's policy with regard to the absorption of the Jewish majority, which tripled during the years 1949-1960, assumed that, despite the differences among ethnic groups, underlying similarities would permit the establishment of the common collective identity. The national educational system, guided by the secular Zionist ideology, pursued the minimization of cultural differences. In the 1950s, the goal was "assimilation," which assumed permeability and certain convergence among all the ethnic groups (Horowitz 1981; Smocha 1993). Later, educational policies aimed at replacing heterogeneity with a common culture based on enlightened, humanistic, Western conceptions of nationalism, freedom, democracy and equality (Kahane 1998). Within a frame of formal equality, policy-makers interpreted the gap in academic achievement between Jewish pupils of European/American origin and those of Middle Eastern background as an ethnic problem. New programs aimed at compensating cultural disadvantages included more hours of schooling, more resources for homogeneously oriental schools, and similar measures. Their effect, however, on the reduction of differences in achievement between Ashkenazi and Sephardic children was only marginal. The search for new mechanisms led authorities to implement during the seventies an educational reform that adopted the structural division of the American system, and fostered the integration of children from different ethnic backgrounds into the same classrooms. Still, these reforms had a slight impact in closing the achievement gap (Nahon 1984; Peled 2001; Shavit 1990).

Both negative labeling and cuitural marginality contributed to Oriental Jews' resentment and alienation. Their support for parties that articulated these feelings, Shas in particular, intensified over time (Peled, 2001). From its beginnings, the party advocated the creation of kindergartens and schools in peripheral areas of the country, where groups from Oriental origin and low income were over-represented, and where unemployment, crime, drug abuse and school failure had been perennial problems (Chen 1995), Oriental Jews living in these areas had particularly

5 Up to the end of the World War I, under Ottoman rule, Sephardim (Oriental Jews) constituted the majority of the Jewish population in Palestine. Under British rule immigration dramatically changed the numerical balance of Ashkenazim and Sephardim. After Independence in 1984, mass immigration from Arab countries brought in large numbers of Sephardim who were relative ly untouched by the encounters with religious and secular Zionism and with Western ideas. 
strong feelings of discrimination, a fertile soil for the diffusion of the new cultural identity advocated by Shas.

\section{"RETURNING TO RELIGION" (T'SHUVA): THE SHAPING OF A NEW CULTURE}

In the course of 2000 and 2006 we conducted research in Jerusalem, in the Tel Aviv satellite town of Petach Tikva and in the dormitory town of Bet Shemesh near Jerusalem, interviewing officials and educators in the Shas network. They justified the need for their schools in terms of ensuring the transmission of the substantive values of Judaism. Few of them blamed discriminatory policies for children's low formal achievement. Neither did they complain about the lack of compensatory mechanisms, or about the lack of compatibility between the Western pedagogic methods and their culture.

Rather, they explained the social failure and moral decline besetting the Sephardim on the experience of rapid-fire secularization, in which immigrants were cut off from the religious habits of their places of origin and more or less forced into a modern way of life. According to an official of the Maayan Hachinuch Hatorani, Oriental Jews' feelings of cultural deprivation and humiliation were the result of the attempt to replace rapidly their ancestral culture with the "enlightened" and Zionist knowledge. In its rhetoric, Shas claims that its educational system has tried, in one of its prominent politicians words, "... to give the Sephardim their home back"leachzir atarah leyoshna- literally "restore the Crown to its old glory". He claimed that "...education is the solution for chazara bet'shuva," (those returning to religion)", and argued, "The secular system was falling apart because of violence, drugs, lack of respect for parents... We do not have problems of violence or drugs... [in our milieu], the relation between parents and child is completely different. They are not friends: their relationship is hierarchical".

Taking as a point of departure the Zionist emphasis on the European Jewish experience, while neglecting and even ignoring the history of Oriental Jews (Almog 1997), Shas leaders have placed the blame on the Israeli history curriculum (especially the centrality it assigns to the Ashkenazi founding fathers, such as David Ben- Gurion and Chaim Weizmann), the teaching of Israeli literature, and social and civic studies, for what they claim has been the destruction of the bases of Judaism and tradition. To Zionist values, they oppose a set of countervailing principles: respect for tradition, obedience of parents and teachers, study of sacred texts, and in general the revival of Oriental Jewish customs and virtues. Against the modernizing view of children as the key to social progress and consolidation of the national ideology, they portray children as the key to the continuity of culture and customs. In the words of an expert in the network's Pedagogical Center, "the studies taught in the national educational system must be replaced by traditional values, [the ones] we learned from our grandparents. Since we ourselves cannot teach them to our children, we need to send them to schools where they will learn [these values]".

The discrepancy between the new schooling proposed by the movement and the basic assumptions of the national educational system may be exemplified in a letter sent to the Shas newspaper "Maayan Hashavua" (the Weekly Spring), in which a reader argued: "Our parents came to Zion with joy, they came to the Holy Land with tears. Did they [come] so that their children would be educated in the negation and dishonor of all Holiness? Are our children 
supposed to admire Hegel and Goethe instead of the Holiness of lsrael? Are they supposed to quote Shakespeare instead of the Song of Songs? What is going to be the source of their Judaism' [will it be] Mathematics and English'? After one hundred and twenty years, when they meet their grandparents, what will their common language be Algebra problem? Chemical formulae?" (Quoted in Chen 1995: 12).

For Shas, education is also a tool for the redrawing of the boundaries of family life, for the attainment of the broader goal, that of bringing people back to traditional religious observance$t$ 'shuva-; the alternative road it proposes to the whole Jewish people. To the secular Zionist goals of a liberal democratic state for the Jewish people, Shas opposes the ideal of a society based on the preservation of traditional values. Its leaders hope that education based on the rediscovery of sacred sources and on ritual practices will be a channel for the return of students' families to religious observance. They are aware that the fulfillment of mitzvoth, a fundamental Jewish concept meaning commandments and good deeds, can only be sustained when it becomes a family experience. The often-quoted image of children reading the weekly portion of the Torah to their parents indicates Shas's purpose of inverting the conventional mechanism of socialization. In the words of Eli Ishai, the political leader of Shas, the growth in the number of children in the schools is a vote of trust for the movement since parents rely on the contents transmitted to the children. (Ynet 23-7-2008).

The growth of the Shas educational system, which was established in the $1990 \mathrm{~s}$ and has been slowly growing ever since, has contributed not only to a sharpening of the major ethnic and cultural subdivisions within the Jewish population, but also to a convergence between ethnicity and religiosity. Its teachers and students are practically all Sephardim, and it has endeavored to attract students not only from ultra-Orthodox and other traditional religious families, but also, and especially, from non-religious backgrounds. The system's reach is not confined to day schools: Shas has generated a variety of additional programs, including after-school activities for children, a youth movement, evening lessons for men and women, and religious learning centers (yeshivas). Thus, Shas has created the infrastructure of a new ethno-religious collective identity.

One of the central themes in Shas education is the institutionalization of precise and differentiated roles for men and women. Until the eighth grade, boys are exposed to both secular and religious studies, but secular studies diminish gradually from the ninth grade on, and the curriculum concentrates on the study of the Talmud and the minutiae of the Halakhah (Jewish law). In conformance with Jewish traditional practice, in which the obligation of studying Torah was particularly focused on men, Shas's expectation is that as many boys as possible will, after finishing school, enroll in specialized religious institutions the Talmud Torah and primary-level yeshivas. As for girls, they receive a broader education than boys in secular matters, since they are expected do go in the labor market to support their families. They are not expected to deepen their religious education, for their traditional function is only to manage the household, and raise children based on religious precepts and moral rules rooted in religion.

The system itself is divided in three different tracks according to the families' degree of religiosity. A principal of an Ultra-Orthodox school in Beit Shemesh said that "you can't mix mature and non-mature material; you must be sure about what you have in hand". Shas schools 
also entice parents, especially non-observant and poor ones, by offering them additional benefits: longer school days (especially valuable for families interested in 'keeping children off the streets'), and transport to and from school. The requirements for enrolment are quite simple: Parents must take care to observe Sabbath, Jewish dietary rules, and proper and respectable behavior, including the prohibition of bad language and streetwise habits. Since teachers keep a check on whether these commitments are being respected, families have incentives to conform. Thus, children from non-religious background became agents of transformation since they socialize their parents into the new norms, customs and "mitzvoth". The pressure from school authorities to take children out of school, a step with high economic and social consequences, inflicts parents who refuse to adopt religious precepts. In the end, Shas's "soft" approach to t shuva is usually successful: children and families change, when necessary, their patterns of behavior, observance, dress, and language, and are absorbed into the new sub-culture.

\section{THE REVIVAL OF TRADITION IN A MODERN CONTEXT}

To place t'shuva in the context of a bureaucratic apparatus is to point to its relationship to modernity and, though some may find this strange, secularization. For if from one perspective tshuva can be seen as a reverse to tradition, or as a reaction against modernity (a point on which both supporters or antagonists of the movement seem to agree), it is also a case of modern religion, because beliefs are transmitted and reinforced, and even codified, by bureaucratic institutions and socialization agencies. Of course, these institutions may not be models of impersonality and transparency, but they are nevertheless quite different from the family and other primary relationships that had ensured the reproduction of religious culture in Jewish communities in Eastern Europe and North Africa.

The placement of $t$ shuva in a modern context also implies to look for the appropriate frameworks that constructs and interprets the systems of knowledge capable of guiding the idea of preservation and renewal of tradition. Among the many new institutions emerging for such purpose, two may exemplify the challenge put by continuity and change when dealing with "the reinvention of tradition". One is "Kisse Rachamim", one of the most elitists - but controversial- yeshivas in Bnei-Brak. Its curriculum places a great deal of emphasis on the renewal of Sephardic pronunciation. Students and teachers rewrite books related to religious themes, and clarify in all the pages the correct spelling and notation.

This strategy coexists with other characteristics of modern educational systems: selectivity, and the encouragement of initiative and innovation. The admission rate is 25 percent of applicants, based on an entrance examination administered by an external committee that applies, in the words of one of the heads of the Yeshiva, "impersonal criteria of selection". Pedagogical methods derive, according to one of the heads of the institution, from those that had been practiced in Tunisia, the country of origin of the founders of the institution. In contrast to the scholastic style of Ashkenazi yeshivas (the pilpul), based on memorization, teaching at this Yeshiva focuses on "understanding rather than 'memorizing, thus encouraging individuality in the approach to the original texts (Gemara, Rashi and others)" with the purpose of allowing students to develop a critical and sharp mind, in order to attain "the only possible truth". 
Another interesting organization that we visited during the research period is the "Research Institute of Education and Behavior," whose goals, in the words of a prominent Shas rabbi, are "to find in the traditional sources the parallel to universal sources", a necessary bridge, for traditional premises can be enriched by new questions deriving from the modern world. In his view, the potential of knowledge developed from rational assumptions is limited, and it must be expanded on the basis of tradition. He strives to codify the original religious sources in a new hierarchical order, derived from the main questions put forth by modern sociology, psychology, pedagogy and other modern types of knowledge. His expectation is that this codification will allow not only a new reading of the ancient texts but, above all, the generation of new answers to questions resulting from what he calls "rational modernity". In the institute, members use new technologies (data bases, connections with the university libraries, and others) to codify information related to topics of contemporary interest, such as the quality of the environment, questions of identity, psychological concerns, and so on. Through the confrontation of both systems of knowledge, they expect to create a new intellectual language capable of embracing the secular questioning with the religious answers, and thus realize the old vision according to which "from Zion will come forth Torah". Our interviewees complained about the lack of symmetry between their world of knowledge and the academic one. They claim to be ready to learn from the new philosophies questions concerning man's life in this world, but they perceive the academic world as closed to religious wisdom. They hope to create a common ground, where they would meet modern academics and ponder the basis of all knowledge. Following the precepts of the Rabbi Ovadia Yosef, they seek a creative compromise with modernity, in which the adaptation of modern forms of teaching and interpretation would allow the voice of traditionalism to be heard in the modern world.

\section{THE TENSION BETWEEN ETHNICITY AND RELIGION}

With the rise of Shas Israel have extended arrangements, which previously operated in the Jewish religious sphere to the ethnic sphere, at least de facto. The party has persuaded the state to create what is in effect a special, strictly Orthodox educational network for children of North African and Middle Eastern parentage. Hitherto the only ethnically based special provision - of education, and implicitly of municipal services in areas with predominantly Arab population was of a discriminatory kind, a truncated citizenship for the remaining Arab population (Louër $2007)^{6}$. The political class did not actively seek to suppress diversity, but neither did they ever seriously consider the notion of a politics of identity as a device to achieve inclusion. In fact affirmative action (not the same thing of course) has existed, as we explained, but for the Arab population to help them gain access to universities. Among the Jewish population poverty and exclusion - the issues that often underlie claims for ethnic recognition - were treated as matters for social policy. Even when, as in the $1970 \mathrm{~s}$, differences of origin were recognized as causes of differential educational achievement, and catch-up programms were devised for the

6 The existence of parallel Ashkenazi and Sephardi Chief Rabbinates can be understood as based on different traditions of worship and religious observance, in which ethnic identity acted as an appendage. 
disadvantaged, this was in no way intended to be an identity-specific education or a basis for any kind of identity politics.

Note, however, that ethnic identity is no more a matter of straightforward labeling here than anywhere else. Thus in this case, despite the universal assumption in daily parlance that schools, clubs, associations and the like gathered under the aegis of Shas political leaders ( $\mathrm{Ha}-\mathrm{Ma}$ 'ayan and $\mathrm{El} \mathrm{Ha-Ma'ayan}$ ) are for the benefit of Sephardim, there is no official mention of ethnic difference in the provisions for these activities and associations: the ethnic belonging is entirely implicit and non-codified, though sustained by elaborate, tacit and informal codes. Shas educational institutions are open to all, but in practice pupils are overwhelmingly Sephardi, though Shas teachers and politicians have spoken to us with pride of their openness, and welcome nonSephardi pupils as a recognition of the quality of the service they offer. Their interest is in not having a numerus clausus, especially since they are a long way from attracting a majority of Sephardi children. Likewise, although the Shas inclination of these institutions is universally recognized, it cannot be officially admitted because that would confirm the political adherence of educational and civic bodies, which is not admissible.

The Sephardi character of the schools is manifested in symbolic markers -dress, physical appearance, music, the liturgical use of Sephardi Hebrew pronunciation, ubiquitous pictures of Ovadia Yosef ${ }^{7}$ - but hardly in the substance of the curriculum, which is heavily religious and ultra-Orthodox, but has little distinctively Sephardi in its content. For example, we found nothing on the 2000 years or more of history of Jews in Arabic-speaking societies. However, by establishing a set of institutional arrangements in response to the needs or traditions of an ethnic group-defined in these cases religiously and to some extent even ideologically- the state set a precedent for something like the group-differentiated rights.

\section{CONCLUSIONS}

The discussion above makes it clear how the educational sphere may be a vehicle creating the appropriate conditions for the construction of new cultural spaces. Shas, is in fact a movement, which takes advantage of the bureaucratic state and the dynamics of democratic politics in order to spread and consolidate a new identity based on a newly formulated ethnic and religious content. This is facilitated by the state's institutionalized response that, rather than establishing mediating mechanisms among the different groups and enhancing the common dimensions of identity, strengthens the demarcation of their cultural distinctiveness. But the pattern of recognition enhanced by Israel's version of the religiously motivated social closure, also characterizes many contemporary religious movements in different areas. Hence, the creation of new ethnic and religious spaces has multiple causes and it turns out to have very interesting political potential, and by no means only in the Israeli context. 


\section{BIBLIOGRAPHY}

ARIAN, A. and M. SHAMIR

The Elections in Israel 1984

Tel Aviv: Ramot Publications, 1986.

ALMOG, O.

The Tzabar.A Portrait

Tel Aviv: Am Oved. (Hebrew), 1997.

BARZILAI, G.

Communities and Law: politics and culture of legal identities.

Ann Arbour, Ml: University of Michigan Press, 2003.

BERMAN, E.

"Sect, subsidy, and sacrifice: an economists' view of Ultra-Orthodox Jews"

Quarterly Journal of Economics, 115(3):905-53, 2000.

CHEN, E.

Orientations and Goals of the Shas Educational System as They Appear in the

Daily Reality of a Talmud Torah and Boy's School.

M.A. Thesis: Tel Aviv University. (Hebrew), 1995.

HOROWITZ, D. and M. LISSAK

Trouble in Utopia: the overburdened polity in Israel

Albany, NY: SUNY Press, 1987.

HOROWITZ, T.

"Assimilation vs. Integration: Immigrant Absorption in the Israeli Educational System"

Pp. 137-157. In Bhatnager, J. (ed.), Educating Immigrants. London: Croom Helm, 1981.

KAHANE, R.

"Informal Agencies of Socialization and the Integration of Immigrant Youth into Society: an Example from Israel”. Pp. 287-307 in E. Leshem and J. T. Shuval (eds.), Immigration to Israel. Sociological Perspectives. New Brunswick: Transaction Publishers, 1998.

LOUËR, L.

To be an Arab in Israel

New York, Columbia University Press, 2007.

NAHON, Y.

Trends in the Occupational Status-The Ethnic Dimension

Jerusalem: Jerusalem Institute for Israel Studies (Hebrew), 1984. 


\section{PELED, Y.}

"A Mystery and Its Name Is Shas"

Pp. 52-73 in Y. Peled (ed.) Shas: The Challenge of the Israeli

Tel Aviv: Yidihot Ahronoth. (Hebrew), 2001.

POPKEWITZ, Th. S.

A Political Sociology of Educational Reform: Power/Knowledge in Teaching, Teacher Education, and Research

New York: Teachers College Press, 1991.

SCHIFMAN, E.

"The Shas system school in Israel"

Nationalism and Ethnic Politics

11, 1, Spring: 89-124, 2005.

\section{SHAVIT, Y.}

"Segregation, Tracking, and the Educational Attainment of Minorities-Arabs and Mizrahi Jews in Israel"

American Sociological Review 55 ( 1) : 115-126,1990.

SMOCHA, S.

"Class, Ethnic and National Cleavages and Democracy in Israel"

Pp. 172-202 in U. Ram (ed.)

The Israeli Society: Critical Perspectives

Tel Aviv: Breirot (Hebrew). 1993.

TESLER, R.

"The Price of Revolution"

Pp. 210-279 in Y. Peled (ed.)

Shas. The Challenge of the Israeli

Tel Aviv: Yidihot Ahronoth. (Hebrew), 2001.

\section{ZAMERET, Z.}

1997 Across a Narrow Bridge

Shaping the education system during the Great Alya. Sde Boquer. Ben Gurion University of the Negev Press, 1997. 